\title{
Разработка бытовых комбинированных приборов абсорбционного типа
}

\author{
А. С. Титлов ${ }^{1 凶}$, Ю.А. Козонова ${ }^{2}$ В.Г. Приймак \\ Одесская национальная академия пищевых технологий, ул. Канатная, 112, Одесса, 65039, Украина \\ ORCID: ${ }^{1}$ 0000-0003-1908-5713, ${ }^{2}$ 0000-0001-9463-0342 \\ $\bowtie$ e-mail: ${ }^{1}$ titlov1959@gmail.com
}

\begin{abstract}
Перспективным, с точки зрения энергосбережения, направлением в современной технике является создание бытовых приборов, объединяющих функции холодильного хранения и тепловой обработки пищевых продуктов, полуфабрикатов и сельскохозяйственного сырья. Из всех типов современного бытового холодильного оборудования таким температурным потенциалом обладают элементы абсорбционного холодильного агрегата ректификатор, дефлегматор и конденсатор. Собственные экспериментальные исследования показали, что введение в состав бытовых абсорбционных холодильных приборов дополнительной тепловой камеры, не приводит к росту энергопотребления и не ухудшает температурные характеристики камер охлаждения. Проведена классификация различных способов подачи бросового тепла в тепловую камеру такого комбинированного холодильного прибора и на ее основе разработаны различные схемы и конструкции.
\end{abstract}

Ключевые слова: бытовая техника, энергосбережение, комбинированный абсорбционный холодильный прибор, дополнительная тепловая камера

\section{Розробка побутових комбінованих приладів абсорбційного типу}

\section{О. С. Тімлов, Ю. О. Козонова, В. Г. Приймак}

Одеська національна академія харчових технологій, вул. Канатна, 112, Одеса, 65039, Україна

\begin{abstract}
Перспективним, з точки зору енергозбереження, напрямком в сучасній техніці є створення побутових приладів, які об'єднують функиї холодильного зберігання $і$ теплової обробки харчових продуктів, полуфабрікатов $i$ сільськогосподарської сировини. 3 усіх типів сучасного побутового холодильного обладнання таких температурних потенціалом володіють елементи абсорбиійного холодильного агрегату - ректифікатор, дефлегматор i конденсатор. Власні експериментальні дослідження показали, щзо введення до складу побутових абсорбиійних холодильних приладів додаткової теплової камери, не приводить до зростання енергоспоживання $і$ не погіршує температурні характеристики камер охолодження. Проведено класифікацію різних способів подачі непридатного тепла в теплову камеру такого комбінованого холодильного приладу і на ї̈ основі розроблені різні схеми $i$ конструкиї.
\end{abstract}

Ключові слова: побутова техніка, енергозбереження, комбінований абсорбиійний холодильний прилад, додаткова теплова камера

(C) The Author(s) 2018. This article is an open access publication

This work is licensed under the Creative Commons Attribution 4.0 International License (CC BY) http://creativecommons.org/licenses/by/4.0/

\section{1. Введение}

Происходящий в настоящее время переход холодильной техники на природные рабочие вещества заставляет разработчиков пересмотреть отношение к абсорбционным холодильным приборам (АХП), которые комплектуются абсорбционными холодильными агрегатами (AXА) и могут рассматриваться как один из альтернативных вариантов перехода на природные хладагенты.

Рабочее тело АХА состоит из водоаммиачного раствора (ВАР) с добавкой инертного газа (водорода, гелия либо их смеси) и является абсолютно экологически безопасным - имеет нулевые значения озоноразруша- ющего потенциала и потенциала «парникового» эффекта [1].

Абсорбционные холодильные приборы имеют и ряд таких уникальных качеств, как [2]:

a) бесшумность, высокая надежность и длительный ресурс, отсутствие вибрации, магнитных и электрических полей при эксплуатации;

б) возможность использования в одном аппарате нескольких источников энергии - как электрических, так и альтернативных (теплота сгорания органического топлива, солнечное излучение, выхлопные газы двигателей внутреннего сгорания, «горячий» поток воздуха вихревой трубы, теплонагруженные элементы радиоэлектронной аппаратуры); 
в) возможность работы с некачественными источниками энергии, в том числе и электрической, в диапазоне напряжения сети $160 \ldots 240$ В.

К достоинствам АХП следует отнести меньшую по сравнению с компрессионными аналогами стоимость, что во многих случаях и определяет их популярность у пользователей.

Абсорбционные холодильники и морозильники, оснащенные горелочными устройствами, широко используются туристами и путешественниками, так как им нет альтернативы в районах с отсутствием электроэнергии.

Вместе с тем, АХП имеют повышенное по сравнению c аналогичными компрессионными моделями энергопотребление. На наш взгляд, такое положение связано не только с несовершенством их холодильного цикла, но и с отсутствием соответствующих научных и инженерных разработок.

Сравнительно невысокая энергетическая эффективность АХП обусловливает и узкую область их применения, в основном, в качестве минихолодильников, и небольшую долю на рынке бытовой холодильной техники [3].

Анализ тепловых режимов АХА показал, что перспективным направлением в энергосбережении может стать разработка бытовых приборов, совмещающих функции холодильного хранения и тепловой обработки пищевых продуктов, полуфабрикатов и сельскохозяйственного сырья [4-6].

В таких комбинированных бытовых приборах теплота, выделяющаяся при реализации холодильного цикла, не отводится в окружающую среду, а направляется в специальную тепловую камеру (ТК). В объеме ТК поддерживается температура выше, чем температура воздуха в помещении.

Эффект энергосбережения достигается за счет того, что температурные режимы в ТК поддерживаются без привлечения дополнительных энергозатрат.

На предварительном этапе разработки бытовых комбинированных приборов был приведен анализ технологий, использующих термическую обработку продуктов, полуфабрикатов и сырья. Показано, что для реализации в быту подавляющего числа пищевых технологий достаточным является диапазон температур $50 . .70{ }^{\circ} \mathrm{C}[7-8]$.

В современной бытовой холодильной технике такой диапазон температур отвода тепла холодильного цикла может быть получен только в АХА [4-6]. Анализ температурных полей теплорассеивающих элементов АХА показал, что необходимым температурным потенциалом (более $70{ }^{\circ} \mathrm{C}$ ) обладает опускной и подъемный участки дефлегматора и ректификатор (рис.1).

В опускном участке дефлегматора и в ректификаторе проходит паровой поток водоаммиачной смеси, который используется для предварительного подогрева потока крепкого ВАР на входе генератора, поэтому отбор тепла в этих зонах влияет на эффективность цикла AXA.

Таким образом проводить отбор тепла на необходимом для работы ТК температурном уровне следует только с полностью теплоизолированного подъемного участка дефлегматора AXA.

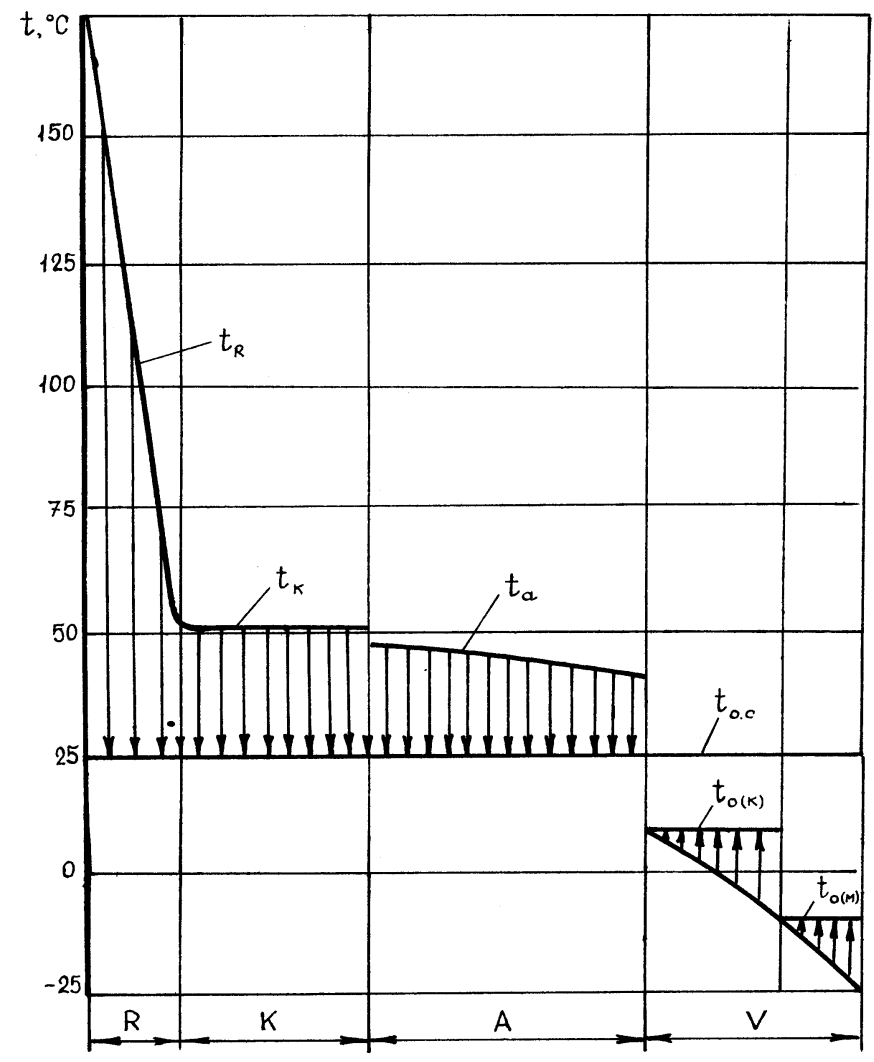

Рисунок 1 - Температурные поля элементов АХА: $\mathrm{R}$ - опускной участок дефлегматора - ректификатор подъемный участок дефлегматора; K - конденсатор; A - абсорбер; V - испаритель.

\section{2. Перспективные конструкции бытовых комби- нированных приборов абсорбционного типа}

Анализ возможных вариантов применения технологических процессов в бытовом комбинированном приборе [7-8] показал целесообразность разработки двух основных типов ТК - воздушного типа и в виде емкости для жидкости (рис.2). В последнем случае ТК могут использоваться для подогрева воды на хозяйственные нужды и для тепловой обработки пищевых жидкостей (пищевых растворов, молока, соков, браги и т.д.).

Разработаны различные конструкции бытовых комбинированных приборов абсорбционного типа, отличающиеся (рис. 3):

a) способом передачи тепла от элементов АХА к ТК (непосредственный контакт дефлегматора и ТК [9], использование промежуточных теплопередающих устройств $[9,10]$, в том числе и с эффектом «осмоса» [10]);

б) расположением ТК в составе комбинированного бытового прибора (сверху холодильного шкафа [9-12] либо в его нижней части [13] или отдельно от холодильного шкафа);

в) конструктивным исполнением ТК (однокамерная $[9,10,12,13]$, двухкамерная [10], наличие диодных ДФТС [9]);

г) источником тепла для ТК и, соответственно, температурным уровнем в ТК (конденсатор [10], подъемный участок дефлегматора $[9,10,12,13])$. 


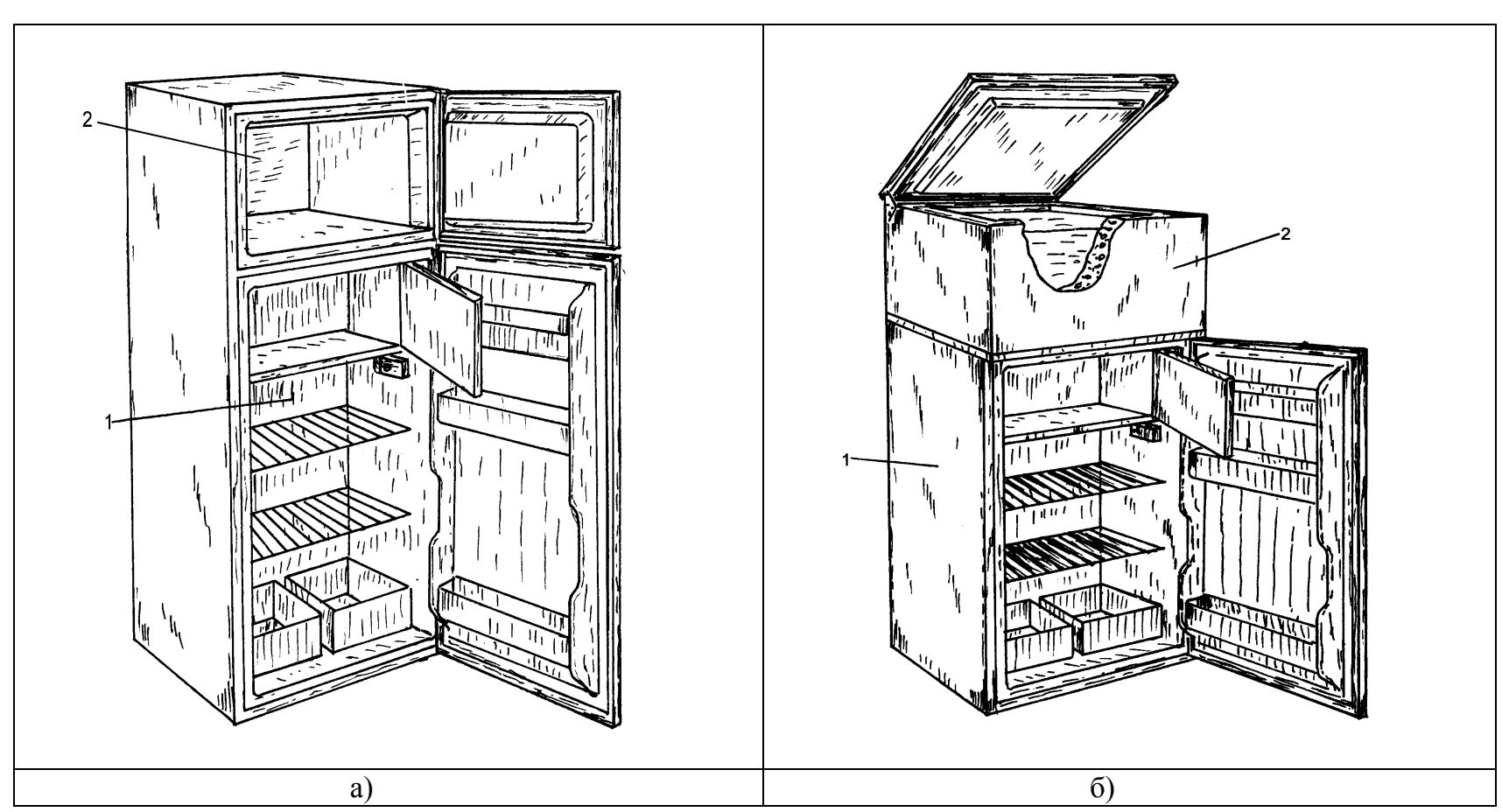

Рисунок 2 - Основные типы бытовых комбинированных приборов абсорбционного типа: а) с воздушной ТК; б) с ТК в виде емкости для жидкости.

\section{Бытовой комбинированный аппарат абсорб- ционного типа с непосредственным контак- том элементов АХА и ТК [12]}

Характерной особенностью схемы является непосредственный тепловой контакт подъемного участка дефлегматора AXA с элементами ТК, что позволяет расширить диапазон температур термической обработки продуктов (в сторону увеличения температуры). Устройство содержит теплоизолированный шкаф 1, разделенный на ТК 2 и холодильную камеру (ХК) 3 (рис. 4). На задней стенке шкафа установлен AXA, содержащий генератор, закрытый теплоизоляционным кожухом 4, жидкостный теплообменник растворов (ЖТО) 5, абсорбер 6, ресивер ВАР 7 , испаритель 8, газовый теплообменник 9, аммиачную магистраль 10, конденсатор 11 и дефлегматор. ТК имеет в задней стенке проем, в котором установлен теплоизолированный блок 12 , выполненный в виде короба. Начальный участок 13 дефлегматора между блоком 12 и кожухом 4 покрыт тепловой изоляцией 14. Средний участок 15 дефлегматора расположен в объеме блока 12 и связан с его дном, выполненным из высокотеплопроводного металла (алюминия). Выходной участок 16 дефлегматора и начальный участок 17 конденсатора располагаются за пределами блока 12. Камеры 2 и 3 имеют раздельные теплоизолированные двери 18 и 19, соответственно.

Дно короба 20 ТК воздушного типа имеет тепловую связь с дном блока 12, а короб 21 ТК, заполненный водой 22 (либо другой жидкостью), имеет тепловую связь с дном короба 12 через свою боковую стенку.

ТК в виде емкости для жидкости имеет верхнюю теплоизолированную крышку 23.
Для интенсификации процессов теплообмена на внутренних поверхностях ТК устанавливаются вертикальные ребра 24, а также тепловые трубы (ТT) или двухфазные термосифоны (ДФТС) Г-образного типа.

Конденсационные участки 25 ТТ или ДФТС расположены на боковых стенках ТК, а испарительные участки 35 - в зоне расположения дефлегматора АХА.

Работа бытового комбинированного прибора абсорбционного типа осуществляется следующим образом. При подаче тепловой нагрузки на генератор АХА происходит выпаривание ВАР, которое сопровождается подачей слабого ВАР на уровень входа в абсорбер.

На выходе генератора температура потоков пара и слабого ВАР составляет $160 \ldots 165^{\circ} \mathrm{C}$ [14]. Перед поступлением в абсорбер слабый ВАР проходит через ЖТО. Образующаяся в генераторе паровая смесь состоит преимущественно из паров аммиака. Очистка смеси от паров воды происходит в дефлегматоре.

Для сохранения высокого температурного потенциала начальный участок дефлегматора 13 закрывают тепловой изоляцией. Как показывает практика, полностью устранить тепловые потери не представляется возможным [15]. Вместе с тем, при использовании в качестве тепловой изоляции кожуха из прессованной базальтовой ваты с наружным диаметром 120 м м, перепад температур на начальном участке дефлегматора не превышает $5^{\circ} \mathrm{C}[16]$.

В среднем 15 и выходном 16 участках дефлегматора паровая смесь конденсируется с выделением теплоты парообразования. Здесь «приемником тепла» являются элементы ТК, в первую очередь, внутренний корпус 20 (в случае камеры воздушного типа) и 21 (в случае камеры, заполненной жидкостью). От внутреннего корпуса ТК тепло передается воздушной среде и далее к загруженным продуктам или непосредственно к жидкости. 


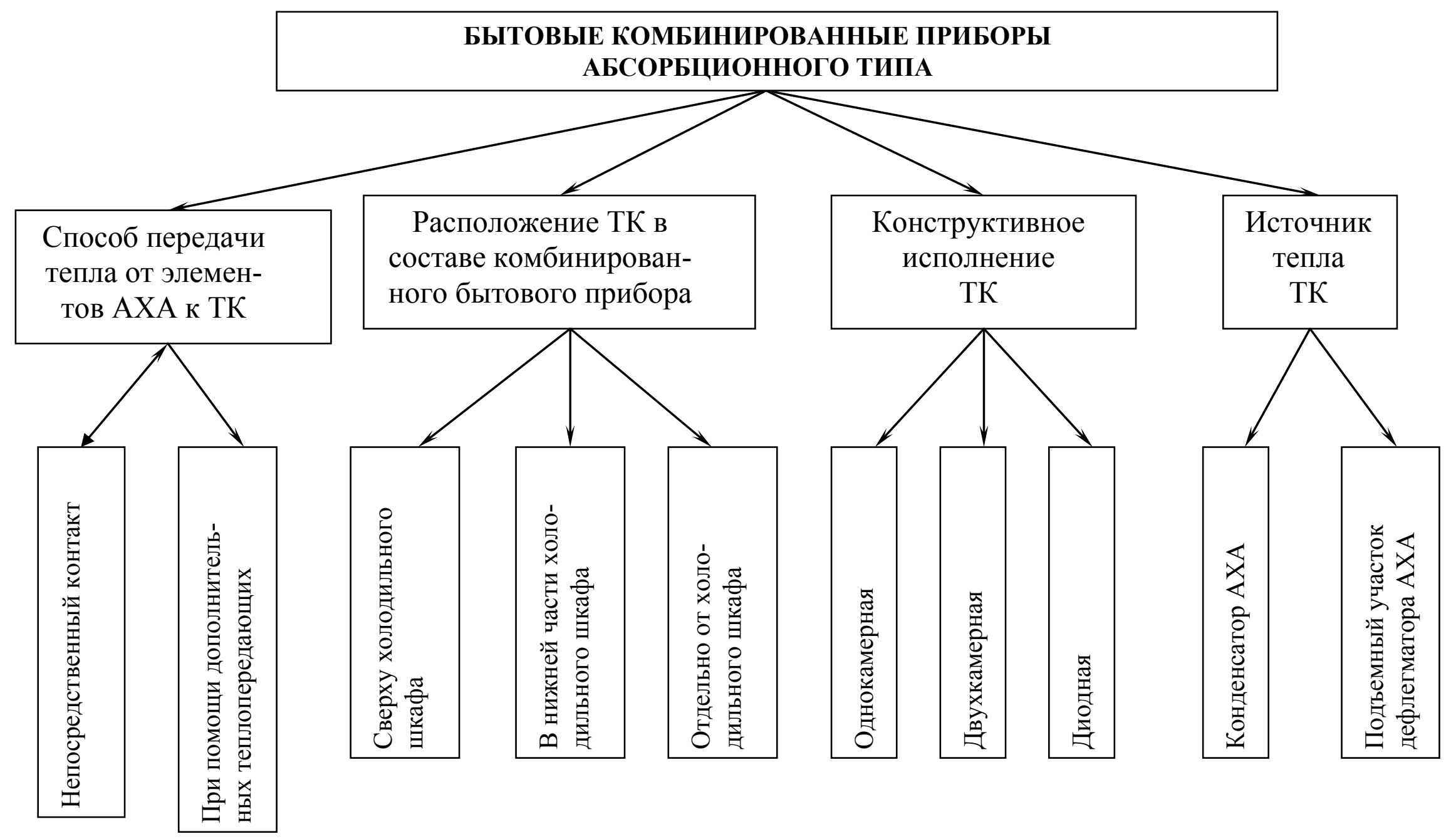

Рисунок 3 - Классификация бытовых комбинированных приборов абсорбционного типа 


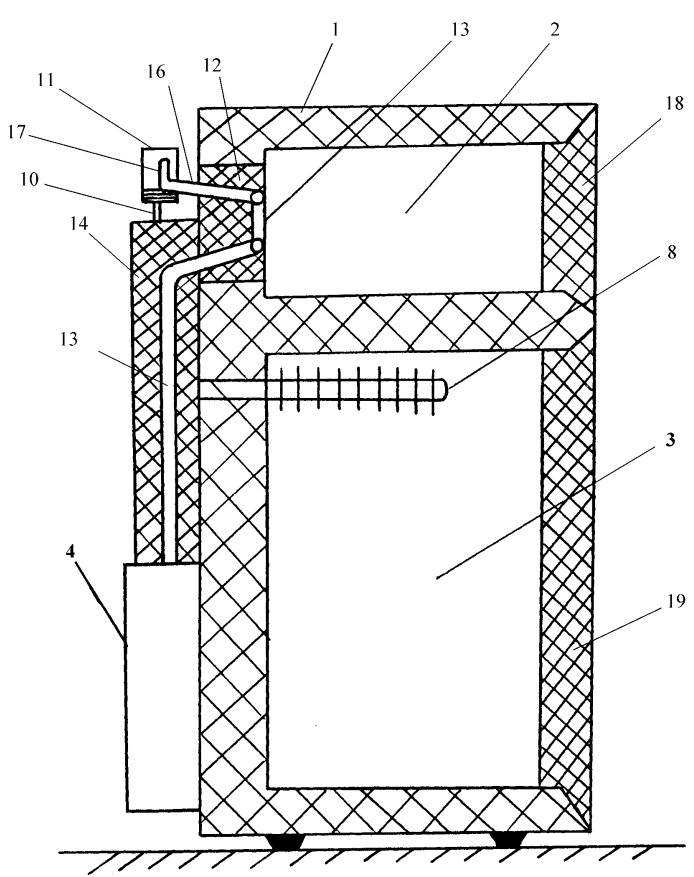

a)

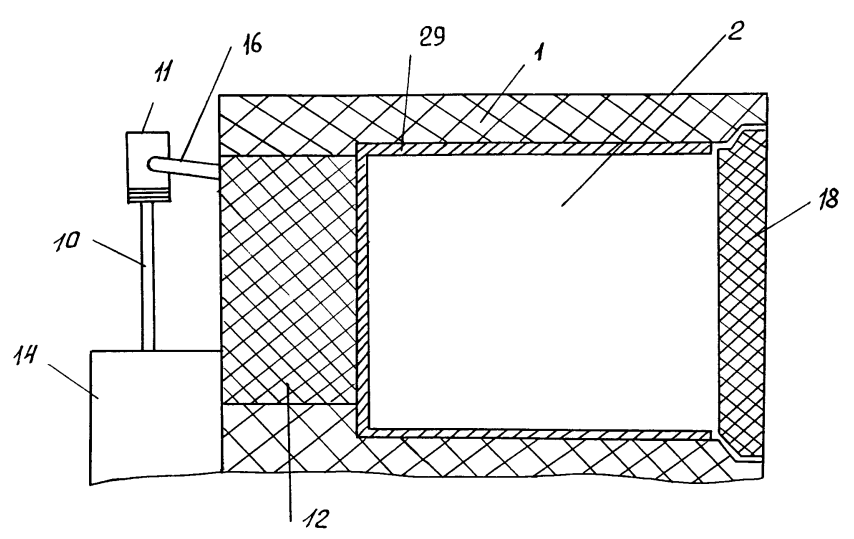

B)

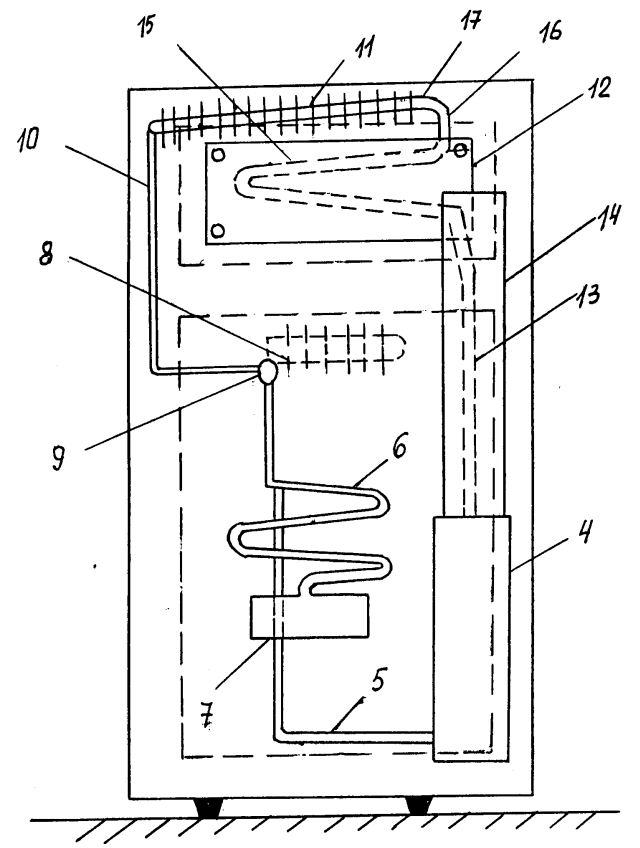

б)

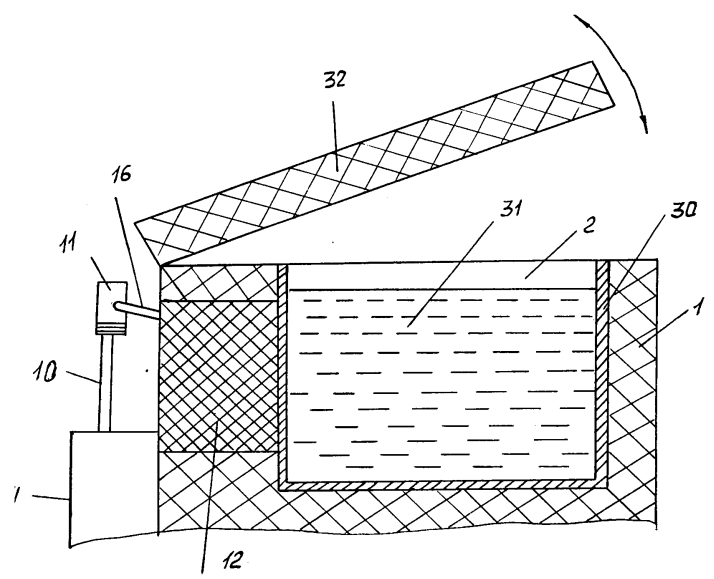

г)

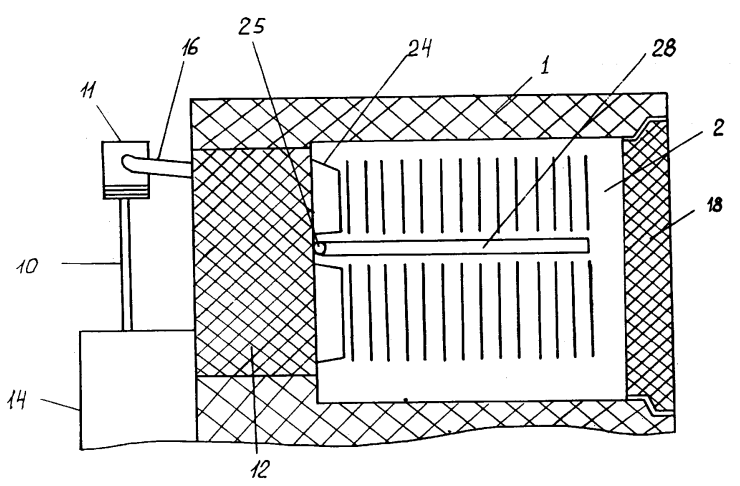

д)

1 - теплоизолированный корпус; 2 - ТК; 3 - ХК; 4 - теплоизоляционный кожух генераторного узла; 5 - ЖТО; 6 абсорбер: 7 - ресивер ВАР; 8 - испаритель АХА; 9 - газовый теплообменник; 10 - аммиачная магистраль; 11 конденсатор; 12 - теплоизолированный блок; 13 - начальный участок дефлегматора; 14 - тепловая изоляция подъемного участка дефлегматора; 15 - средняя часть дефлегматора; 16 - выходной участок дефлегматора; 17 начальный участок конденсатора; 18 - дверь ТК; 19 - дверь ХК; 20(21) - внутренний алюминиевый корпус ТК воздушного (жидкостного) типа; 22 - жидкий наполнитель ТК; 23 - крышка ТК; 24 - оребрение; 25(26) - испаритель (конденсатор) ТТ или ДФТС.

Рисунок 4 - Бытовой комбинированный прибор абсорбционного типа с непосредственным контактом элементов АХА и ТК: а) разрез (вид сбоку); б) вид сзади; в) ТК воздушного типа; г) ТК в виде жидкостной емкости;

д) ТК воздушного типа с элементами интенсификации 
В дефлегматоре из паровой смеси конденсируются пары воды, при этом флегма стекает обратно в генератор. Очищенный пар аммиака поступает в начальный гладкий участок 17 конденсатора и далее в оребренную его часть. В конденсаторе пары аммиака сжижаются, и конденсат стекает в магистраль 10, которая связана с входом испарителя АХА, расположенного в ХК. По пути в испаритель жидкий аммиак переохлаждается в газовом теплообменнике. В испарителе происходит испарение переохлажденного аммиака в среду инертного газа при низком парциальном давлении, при этом реализуется процесс производства холода на температурном уровне минус $30 \ldots$ минус $5{ }^{\circ} \mathrm{C}$. Насыщенная холодная парогазовая смесь (ПГС) поступает в нижнюю часть абсорбера и движется противотоком слабому BAP, стекающему из верхней части. В процессе тепломассообмена между потоками ПГС и слабого ВАР пар аммиака поглощается с выделением теплоты абсорбции, которая отводится в окружающую среду. Насыщенный поток ВАР через ресивер и ЖТО поступает на вход генератора. Очищенный от паров аммиака инертный газ через газовый теплообменник поступает на вход испарителя и цикл работы АХА замыкается.

Так как работа бытового АХП, как правило, осуществляется циклично и при достижении заданной температуры в ХК подача тепловой нагрузки либо прекращается, либо уменьшается, то подача пара в дефлегматор AXА прекращается. В этом случае для поддержания заданного температурного режима ТК подключается дополнительный электронагреватель. При включении в работу АХА и начале теплового воздействия на ТК система управления отключает электронагреватель.

Электронагреватель используется и для работы в момент загрузки продукта (для ускорения времени выхода на заданный режим). Особенно актуально это для ТК в виде емкости для жидкости, имеющей высокую теплоемкость.

Эффективность бытового комбинированного прибора абсорбционного типа возрастет, если внутренние поверхности ТК будут выполнены как единое целое. В этом случае будет организована эффективная тепловая связь дефлегматора АХА со всеми стенками ТК.

Эффективность работы ТК воздушного типа дополнительно возрастет, если будет установлено оребрение на внутренних поверхностях. В этом случае за счет развития поверхности теплообмена снизится термическое сопротивление цепочки «дефлегматор АХА - воздушная среда в ТК» и увеличится уровень температур термической обработки продуктов. Эту же тепловую задачу можно решить и при помощи ТТ или ДФТС, обладающих низким внутренним термическим сопротивлением, причем их применение позволит снизить толщину стенки внутреннего корпуса ТК, особенно в крупногабаритных моделях.

\section{Бытовые комбинированные приборы абсорб- ционного типа с промежуточными теплопере- дающими устройствами}

Наиболее простой в конструктивном исполнении является схема с промежуточными теплопередающими устройствами, которая предполагает минимум изменений в составе АХA.
Устройство [11], приведенное на рис. 5, содержит холодильный шкаф 1 , ТК 2 и АХА, включающий генератор 3, покрытый изоляционным кожухом 4, дефлегматор 5, конденсатор 6, магистраль жидкого аммиака 7, уравнительную магистраль 8, абсорбер 9, ресивер жидкого ВАР 10, ЖТО 11 и испаритель (на рис. 6.5 не показан). В состав устройства входит также ДФТС 12, транспортная зона 13 которого покрыта теплоизоляцией 14, а конденсационная зона 15 связана с ТК. Крепление испарительной зоны ДФТС осуществляется хомутами. В зоне контакта дефлегматора АХА и испарительной зоны ДФТС находится сжатый ВПЯМ с медным каркасом 16. ТК имеет теплоизолированный корпус 17 и дверь 18. Крепление конденсационного участка ДФТС 15 к стенке внутреннего корпуса ТК осуществляется при помощи $\Omega$-образного профиля 19. Прижим $\Omega$-образного профиля 19 к стенке осуществляется при помощи разъемных болтовых соединений 20. Зона контакта $\Omega$-образного профиля 19 и стенки 16 заполнена теплопроводной пастой 21 .

При подводе тепловой нагрузки осуществляется генерация пара в генераторе и циркуляция ВАР между абсорбером и генераторным узлом через ресивер жидкого ВАР и ЖТО. Паровая смесь по каналу дефлегматора поступает в конденсатор. Теплота конденсации паров воды передается от стенки подъемного участка дефлегматора через сжатый высокопористый ячеистый материал (ВПЯМ) к испарительной зоне ДФТС, частично заполненной теплоносителем. Образующийся пар проходит через транспортную зону ДФТС и поступает в зону конденсации, где сжижается с отводом теплоты фазового перехода, которая идет на подогрев полезного объема ТК. Конденсат теплоносителя стекает в зону испарения и цикл ДФТС повторяется.

Для снижения тепловых потерь в окружающую среду транспортная зона ДФТС и подъемный участок дефлегматора закрыты теплоизоляционным материалом. Толщина теплоизоляции выбирается с таким расчетом, чтобы обеспечить практически полную очистку пара аммиака на входе в конденсатор. Это позволяет использовать для подогрева ТК всю теплоту дефлегмации.

Используемый сжимаемый ВПЯМ имеет скелет из металла с высокой теплопроводностью, например, из меди. Подбирая пористость ВПЯМ и толщину пластины ВПЯМ можно при сжатии контактирующих поверхностей обеспечить заполнение воздушного зазора материалом с высокой теплопроводностью. Особенно это актуально при контакте цилиндрических поверхностей, где соприкосновение идет по образующей. Здесь может иметь место также неплоскостность и непараллельность. При стягивании канала дефлегматора и зоны испарения ДФТС хомутами ВПЯМ сжимается, что приводит к уменьшению пористости и заполнению воздушного зазора материалом с высокой эффективной теплопроводностью.

Использование профиля 19 для крепления конденсационного участка ДФТС на внутренней стенке полезного объема 16 осуществляется при помощи болтовых соединений 20. В зоне контакта контактирующих поверхностей 16 и 19 находится теплопроводная паста

Конструкция бытового комбинированного прибора, имеющего две ТК с различными температурными уровнями, приведена на рис. 6 [9]. 

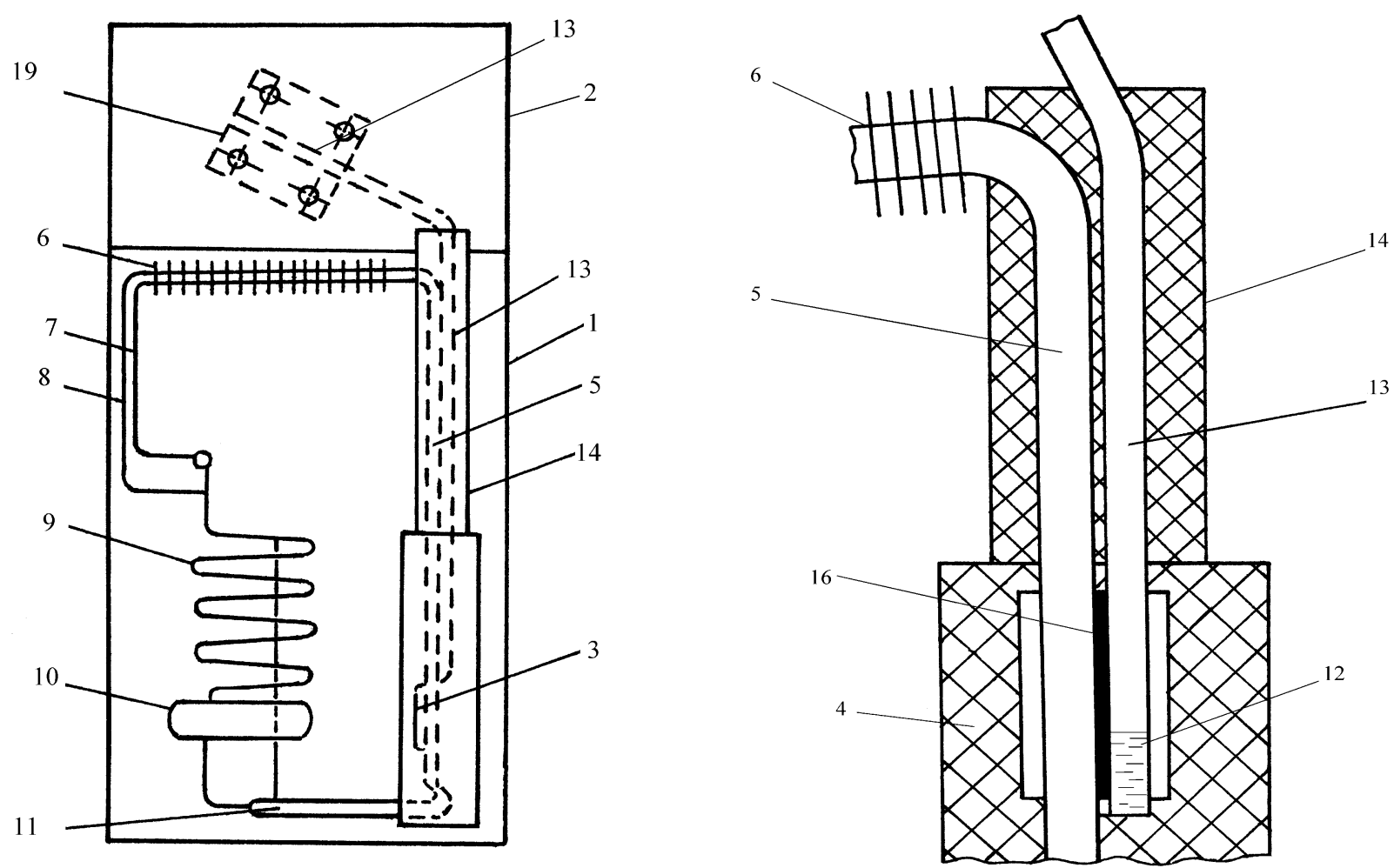

a)

б)

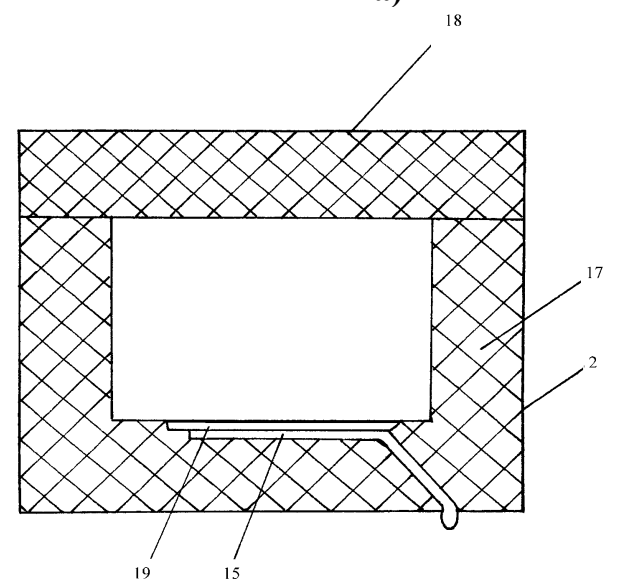

B)

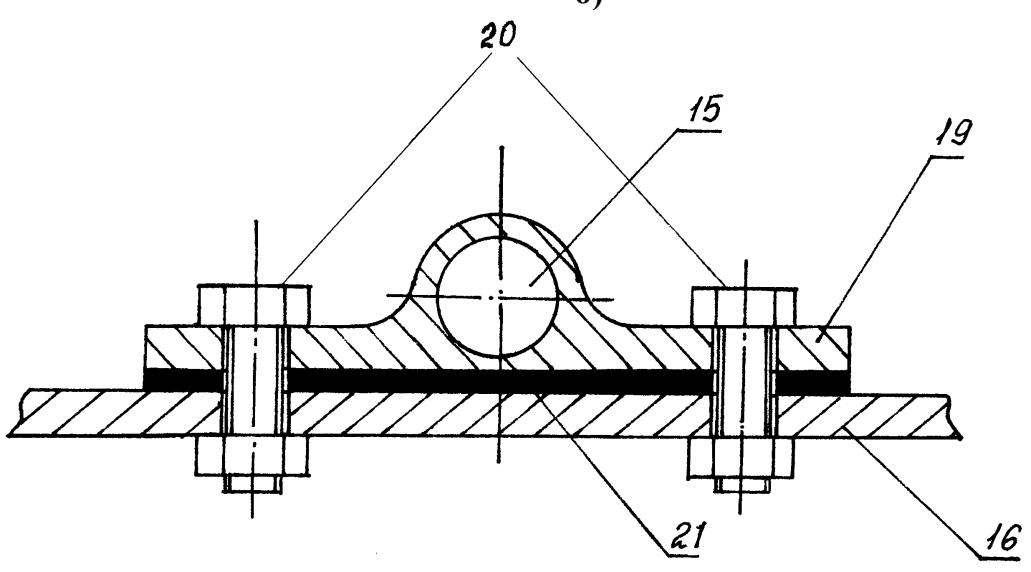

г)

1 - холодильный шкаф; 2 - ТК; 3 - генераторный узел; 4 - теплоизоляция генераторного узла; 5 - дефлегматор; 6 - конденсатор; 7 - магистраль жидкого аммиака; 8 - уравнительная магистраль; 9 - абсорбер; 10 - ресивер жидкого ВАР; 11 - ЖТО; 12,13,15 - испарительная, транспортная и конденсационная зона ДФТС, соответственно; 14 - теплоизоляция; 15 - конденсатор ДФТС; 16 - ВПЯМ; 17 - теплоизоляционный корпус; 18 - дверь ТК; 19 - подложка зоны конденсации ДФТС; 20 - болты крепления; 21 теплопроводная паста в зоне теплового контакта.

Рисунок 5 - Бытовой комбинированный прибор абсорбционного типа с промежуточным теплопередающим устройствам: а) вид сзади: б) схема тепловой связи дефлегматора АХА и ДФТС; в) схема установки конденсационного участка ДФТС; г) схема тепловой связи конденсатора ДФТС с корпусом ТК.

Устройство содержит холодильный шкаф 5 с АХА на задней стенке. В состав АХА входит дефлегматор 4, конденсатор 13, канал жидкого аммиака 8, уравнительная магистраль 7, а также абсорбер, испаритель, генераторный узел, ЖТО и абсорбер, которые на рис. 6.6 не показаны.

В целях снижения тепловых потерь в окружающую среду генераторный узел и частично дефлегматор 4 закрыты теплоизоляционным кожухом 6.
Во внутренней полости дефлегматора и конденсатора аксиально установлены стаканы 3 и 12, в которых размещены испарительные участки ДФТС. Конденсационные участки ДФТС 10 и 11 связаны в тепловом отношении с тепловоспринимающими поверхностями ТК 9 и 1 , соответственно.

ДФТС, установленный в дефлегматоре, заправлен этиловым спиртом, а ДФТС, установленный в конденсаторе - диэтиловым эфиром. Первый ДФТС осуществ- 
ляет передачу тепла на уровне от 60 до $80^{\circ} \mathrm{C}$, а второй - на уровне $50{ }^{\circ} \mathrm{C}$. Рабочий уровень температур ТК 1 составляет $50 \ldots 70{ }^{\circ} \mathrm{C}$ (высокотемпературная ТК), а ТК 9 $-35 . . .45^{\circ} \mathrm{C}$ (среднетемпературная ТК).

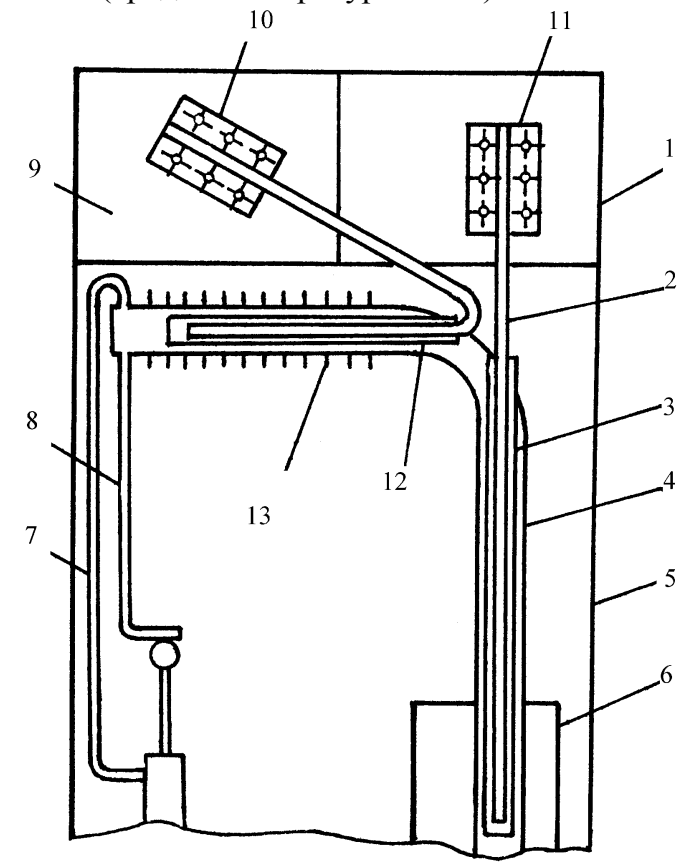

1 - высокотемпературная ТК; 2 - высокотемпературный ДФТС; 3 - стакан высокотемпературного ДФТС; 4 - подъемный участок дефлегматора; 5 - ХК; 6 - генераторный узел АХА; 7 - уравнительная магистраль; 8 магистраль жидкого аммиака; 9 - среднетемпературная ТК; 10(11) - конденсационный участок (среднетемпературной) высокотемпературной ТК; 12 - стакан среднетемпературного ДФТС; 13 - конденсатор АХА.

Рисунок 6 - Конструкция бытового комбинированного прибора абсорбционного типа, имеющего две ТК с различными температурными уровнями

Преимущества конструкции бытового комбинированного прибора с двухтемпературными ТК состоят в следующем:

a) расширяются функциональные возможности бытовых приборов за счет использования тепла с различными температурными уровнями;

б) обеспечивается более полное использование имеющихся источников тепла, в частности, дефлегматора и конденсатора АХА.

Конструкция бытового комбинированного прибора абсорбционного типа, в котором используется температурный потенциал окружающей среды, приведена на рис. 7 .

Устройство [10] содержит холодильный шкаф с ТК 3. Полезный объем 1 ТК закрыт теплоизоляцией 2. В объеме теплоизоляции 2 расположены ДФТС. Испарительные участки 6,7 ДФТС связаны в тепловом отношении со стенкой корпуса ТК, а конденсационные участки 4 и 9 - со стенками внутреннего корпуса 1.

Конструкция ТК с диодными ДФТС предназначена, преимущественно, для использования в качестве емкости для жидкости. Емкость может заполняться водой, которую необходимо подогреть для бытовых

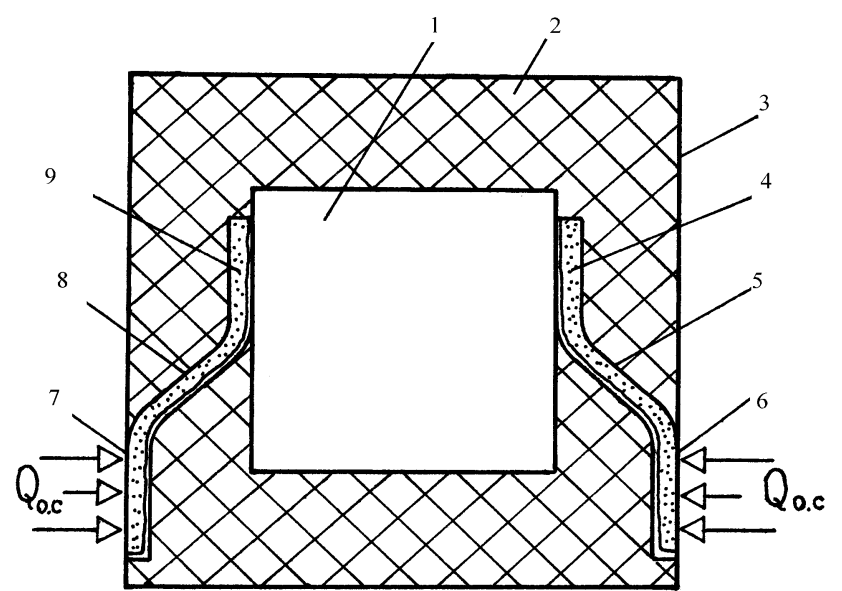

1 - полезный объем ТК; 2 - теплоизоляционный корпус; 3 - ТК; 4(9) - конденсатор ДФТС; 5(8) - транспортная зона ДФТС; 6(7) - испарительная зона ДФТС.

Рисунок 7 - Конструкция ТК с диодными ДФТС

нужд, например, для мытья посуды в сельской местности, где в основном отсутствует горячее водоснабжение. Колодезная или водопроводная вода даже в летнее время имеет температуру не выше $16 \ldots 18^{\circ} \mathrm{C}$, а температура окружающего воздуха $25 \ldots 30{ }^{\circ} \mathrm{C}$. Во время наполнения ТК имеет место температурный напор $\approx$ $10 \ldots 15^{\circ} \mathrm{C}$. Наличие температурного напора между наружным корпусом и внутренним вызывает генерацию паров теплоносителя, частично заполняющего испарительную зону ДФТС 6 и 7. Пар теплоносителя поступает в зоны конденсации ДФТС 4 и 9, связанных в тепловом отношении со стенками внутреннего корпуca, сжижается и отдает теплоту конденсации для нагрева воды, находящейся в емкости. При нагреве воды до температуры окружающего воздуха и выше ДФТС «отключаются».

«Выключение» ДФТС достигается тем, что теплоноситель скапливается в зонах испарения 6 и 7, которые имеют температуру ниже, чем в зонах конденсации 4 и 9. Таким образом, достигается "опрокидывание" испарительно-конденсационного цикла ДФТС. Можно сказать, что ДФТС в рассмотренном случае работают в режиме «теплового диода».

Расчеты показали, что при начальной температуре воды в ТК $16^{\circ} \mathrm{C}$, температуре окружающего воздуха $25^{\circ} \mathrm{C}$ и тепловой нагрузке ДФТС 10 Вт вода объемом 40 литров будет нагреваться до температуры $50{ }^{\circ} \mathrm{C}$ в 1,5 раза быстрее, чем при отсутствии "диодных" ДФТС, связывающих внутренний корпус с наружным.

Несмотря на удобство для потребителя в размещении ТК в верхней части шкафа бытового комбинированного прибора такая компоновка нерациональна с тепловой точки зрения, особенно в случае холодильника с НТО. Если ТК установлена сверху НТО, то для минимизации тепловых перетечек необходима установка теплоизоляции значительной толщины.

Расположение ТК в нижней части шкафа (под ХК) более рационально с тепловой точки зрения, но невозможно при использовании термосифонных теплопередающих устройств, так как в них передача тепла осуществляется снизу - вверх. 
Для установки ТК в нижней части шкафа в зоне ХК предлагается использовать осмотическое теплопередающее устройство (ТПУ) [13] , которое работает с использованием эффекта осмоса - самопроизвольного перехода молекул растворителя через полупроницаемую перегородку - мембрану [17, 18].

Эффект осмоса позволяет осуществлять перенос молекул растворителя в режиме противодавления через мембранную перегородку, т.е. реализуется своеобразный режим работы перекачивающего насоса.

Исследования показали реальность использования эффекта осмоса в ТПУ и теплоиспользующих холодильных машинах [17]. В частности, в представленной ниже конструкции бытового комбинированного прибора абсорбционного типа использование осмотического ТПУ позволяет осуществлять передачу тепла сверху вниз и, следовательно, расположить ТК в нижней части шкафа. Конструкция комбинированного бытового комбинированного прибора абсорбционного типа содержит (рис. 8) теплоизолированный шкаф 1, разделенный теплоизолированными перегородками 2 и 3 на НТО 4, ХК 5 и ТК 6. На задней стенке шкафа установлен АХА, в состав которого входит генератор 7, дефлегматор 8, конденсатор, абсорбер, ЖТО, низкотемпературный испаритель 13, установленный в НТО, и высокотемпературный испаритель 14, установленный в ХК. Генератор закрыт теплоизоляционным кожухом 15. В ТК 6 установлена вертикальная оребренная теплорассеивающая панель 16.

В нижней части генератора установлен источник тепла 17. осмотическое ТПУ содержит испаритель 18 , выполненный по типу перекачивающего термосифона, магистраль крепкого солевого раствора 19, имеющую внешнее оребрение, транспортную магистраль 20, конденсатор 21 и мембранный блок 22, разделенный полупроницаемой перегородкой (мембраной) 23 на полость солевого раствора 24 и полость растворителя 25. Часть конденсатора, расположенная за пределами ТК 6, имеет внешнее оребрение. Между дефлегматором АХА и испарителем ТПУ имеется зона тепловой связи 26. Конденсатор ТПУ 21 закреплен на задней стенке панели 16.

Полость 24, испаритель 18 и магистраль 19 заполнены солевым раствором до уровня $\nabla 1$. Магистраль 19 в рабочем режиме заполнена крепким (обедненным по растворителю) солевым раствором. Полость 25 блока 22 и нижняя часть конденсатора 21 заполнены жидким растворителем до уровня $\nabla 2$.

Работу бытового прибора комбинированного рассмотрим на примере абсорбционного однокамерного холодильника с НТО типа "Кристалл-408" АШ-150. Рабочий уровень температур дефлегматора составляет от 170 (вход) до $80{ }^{\circ} \mathrm{C}$ (выход из изоляционного кожуха 15). Испаритель осмотического ТПУ выполнен из капилляра с внутренним диаметром 2 мм. В качестве полупроницаемой перегородки 23 используется мембрана типа МГА-100 [17], селективная к молекулам воды (т.е. пропускает только молекулы воды). Для механической прочности мембрана армируется нихромовой подложкой. Полная поверхность мембраны составляет $64 \mathrm{~cm}^{2}$. С учетом пористости нихромовой подложки (10\%), рабочая поверхность перегородки 23 составляет $6,4 \mathrm{~cm}^{2}$. В качестве рабочего тела осмотического ТПУ используется водный раствор бромистого лития, обладающий

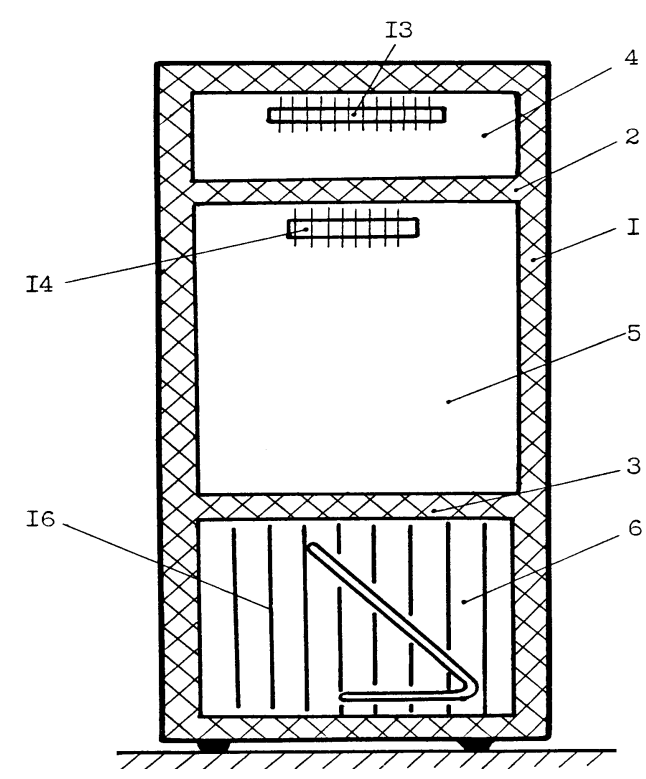

a)

1 - теплоизолированный шкаф; 2,3 - перегородки; 4 - 1 - теплоизолированный шкаф; 2,3 - перегородки; 4 - НТО; 5 - ХК; 6 - ТК; 13(14) - испаритель НТО(ХК); 16 - оребрение ТК.

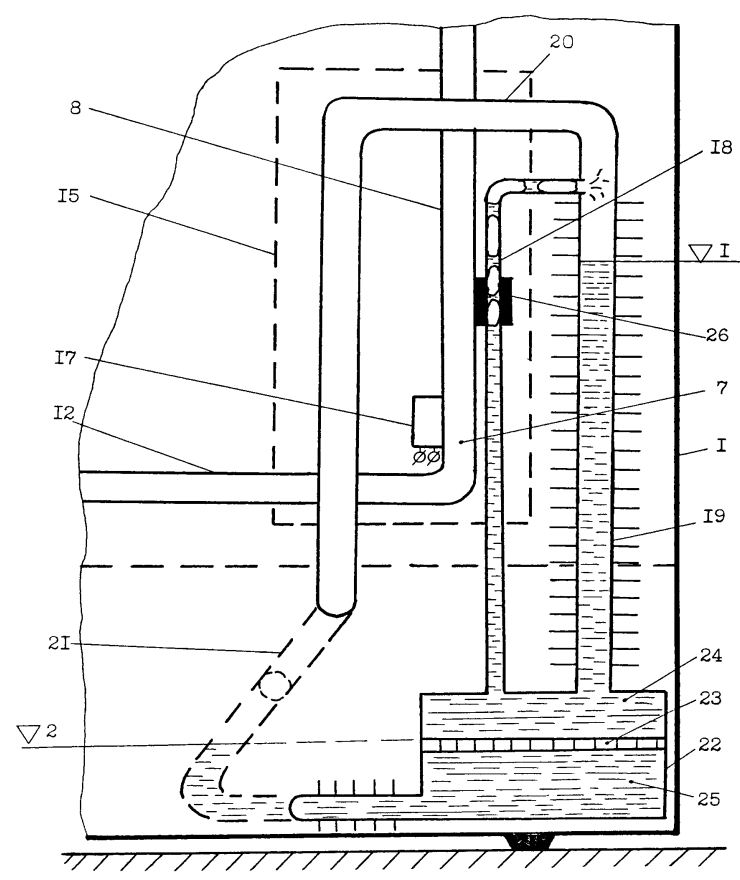

б)

1 - ХК; 7 - генератор; 8 - подъемный участок дефлегматора; 12 - ЖТО; 15 - теплоизоляционный кожух генераторного узла; 17 - источник тепла; 18 - перекачивающий термосифон ТПУ; 19 - сливная магистраль крепкого солевого раствора; 20(21) - конденсатор ТПУ; 22 - мембранный блок; 23 - полупроницаемая мембрана; 24 - полость крепкого солевого раствора; 25 - полость растворителя (воды); 26 - сжатый ВПЯМ.

Рисунок 8 -Бытовой комбинированный прибор абсорбционного типа с нижним расположением ТК и осмотическим ТПУ: а) общий вид бытового комбинированного прибора с нижним расположением ТК; б) схема работы осмотического ТПУ. 
высоким осмотическим давлением. Так, например, при массовой концентрации водного раствора бромистого лития 3,0\% его осмотическое давление составляет 0,45 МПа, при массовой концентрации $18 \%$ 2,84 МПа, а при массовой концентрации $36 \%-6,09$ МПа [17].

Заправку ТПУ проводят таким образом, чтобы в начальный момент раствор не попал в конденсатор 21 и полость 25 мембранного блока. Объем заправки раствора подбирается так, чтобы в рабочем режиме уровень крепкого раствора в магистрали 19 находился на отметке $\nabla 1$, которая находится выше уровня тепловой связи 26 дефлегматора АХА и испарителя ТПУ. Надежную тепловую связь обеспечивают при помощи медных хомутов. Панель 16 , с которой жестко связан конденсатор ТПУ 21, выполняют из алюминия.

Через тепловой контакт 26 осуществляется передача тепла от дефлегматора 8 к перекачивающему термосифону ТПУ, при этом осуществляется нагрев и выпаривание раствора бромистого лития. Нормальная температура кипения воды $100{ }^{\circ} \mathrm{C}$, бромистого лития $1265^{\circ} \mathrm{C}[18]$, поэтому в паре находится только растворитель-вода. Перекачивающий термосифон ТПУ работает в режиме подъема жидкости, т.е. образующиеся пузырьки пара проталкивают в верхнюю часть и порции жидкости. Обедненный по растворителю (воде) раствор сливается в магистраль 19 , а пары поступают в транспортную магистраль и далее в конденсатор осмотического ТПУ. Транспортная магистраль осмотического ТПУ полностью расположена в кожухе генераторного узла АХА. Это сделано для снижения тепловых потерь в окружающую среду, т.е. для более полного использования теплоты дефлегмации для нагрева ТК.

Сжижение паров воды осуществляется в конденсаторе осмотического ТПУ. Теплота конденсации через внешнюю оребренную панель 16 рассеивается в объеме ТК, чем и обеспечивается рабочий уровень температур $50 \ldots 70{ }^{\circ} \mathrm{C}$. Вода стекает в нижнюю часть конденсатора осмотического ТПУ и поступает в полость 25 блока 22. В рабочем режиме жидкость находится на уровне $\nabla 2$, который превышает горизонтальный уровень расположения перегородки 23. На своем пути в блок 22 поток конденсата охлаждается. Интенсификация охлаждения достигается посредством установки внешнего оребрения в зоне, находящейся за пределами ТК. В магистрали 19 осуществляется охлаждение крепкого бромистолитиевого раствора, поступающего в полость 24. Это необходимо для того, чтобы обеспечить интенсивное поглощение молекул растворителя (воды) молекулами соли (бромистого лития). Полупроницаемая перегородка 23 пропускает сквозь себя только молекулы воды, поэтому в динамическом равновесии результирующий поток направлен из полости 25 в полость 24. Перекачка молекул через мембрану компенсирует их отток из испарителя ТПУ. Интенсивная циркуляция раствора в полости 24 обеспечивается работой перекачивающего термосифона 18. Циркуляция приводит к перемешиванию пограничного слоя в полости 24 возле мембраны 23 и интенсивному процессу связывания молекул воды.

В рабочем режиме мембрана должна обеспечивать перекачку молекул растворителя (воды) через противодавление, определяющееся разностью уровней $\nabla 1-\nabla 2$. Максимальный перепад высот в рассматриваемом случае не превышает одного метра. Плотность водного раствора бромистого лития при массовой концентрации
$25 \%$ составляет 1800 кг/м³ . Следовательно, максимальная величина противодавления не превышает 0,02 МПа.

Проведенные экспериментальные исследования [17] показали, что мембраны МГА-100 позволяют осуществлять перекачку через $1 \mathrm{~cm}^{2}$ рабочей поверхности количество воды, эквивалентное тепловой мощности $11 \ldots 12$ Вт, т.е. предельный тепловой поток для мембраны с рабочей поверхностью $6,4 \mathrm{~cm}^{2}$ при противодавлении $0,30 \ldots 0,35$ МПа составляет 70...75 Вт. Вместе с тем, предельный тепловой поток, который можно снять с дефлегматора AXА типа АШ-150, не превышает 30 Вт.

Таким образом, в рассматриваемом случае мембрана МГА-100 работает с запасом, как по тепловому потоку, так и по противодавлению.

Несмотря на минимум перетечек тепла между ТК и ХК, которые достигаются в бытовом комбинированном приборе абсорбционного типа с осмотическим ТПУ, полностью избавится от них не удается.

Для устранения взаимного теплового влияния ТК и камер АХП была разработана конструкция бытового комбинированного прибора абсорбционного типа с отдельно расположенными камерами (рис.9). Кроме этого такая конструкция позволяет выполнять относительно свободную компоновку бытового комбинированного прибора в пространстве.

Тепловая связь между ТК и подъемным участком дефлегматора осуществляется при помощи гибких термосифонов, причем термосифоны могут быть как двухфазные, так и однофазные. Обязательным условием будет установка теплоизоляционного кожуха на транспортной зоне между дефлегматором и тепловоспринимающими поверхностями ТК, а для однофазных термосифонов необходимо предусмотреть возвратную магистраль.

Система теплопередачи на основе гибких термосифонов проста в изготовление и может быть установлена непосредственно в месте расположения бытового комбинированного прибора. Теплоноситель однофазного термосифона - вода.

Подъемная магистраль однофазного термосифона может быть непосредственно связана с объемом ТК, выполненной в виде жидкостной емкости.

В этом случае нагреваемая жидкость будет циркулировать между дефлегматором и ТК в режиме естественной конвекции, т.е. будет организован своеобразный циркуляционный контур.

В этой схеме отсутствуют промежуточные теплопередающие устройства и термической сопротивление между источником тепловой нагрузки и объектом воздействия (жидкостью) минимально.

Следует отметить, что внутреннее термическое сопротивление термосифонов, в том числе и однофазных незначительно, по сравнению с контактным термическим сопротивлением в зонах отвода и подвода тепла. Поэтому вывод из тепловой схемы контактных термических сопротивлений вносит определяющий вклад в интенсификацию теплопередачи.

Перспективной с точки зрения использования бросового тепла представляется и схема комбинированного бытового аппарата абсорбционного типа, в которой в качестве источника тепловой нагрузки генератора AXА используется горелочное устройство, а вытяжной канал отходящих газов, имеющих температуру $350 \ldots 450{ }^{\circ} \mathrm{C}$ [19], связан с тепловоспринимающими поверхностями ТК (рис. 10). 


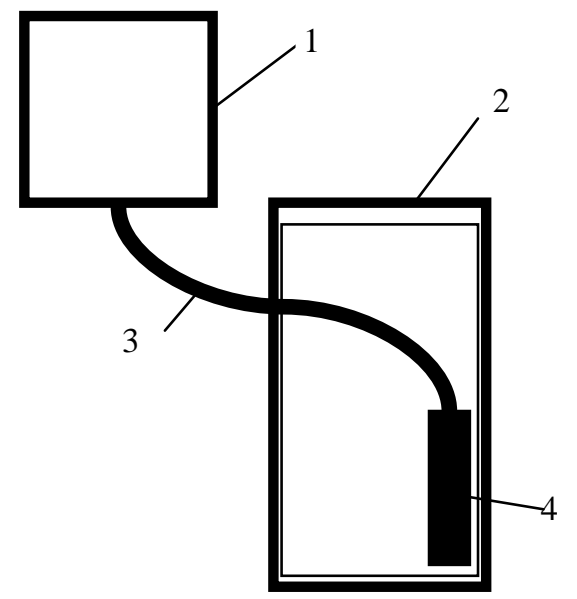

a)

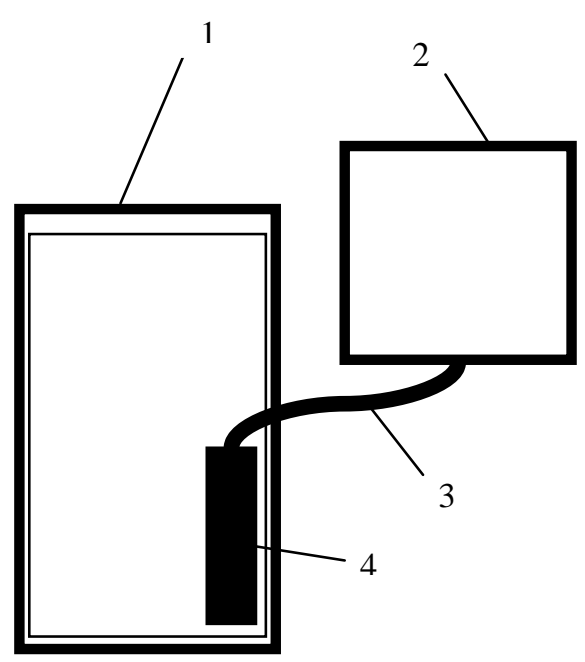

б)

1 - корпус ХК; 2 - ТК; 3 - промежуточное гибкое теплопередающее устройство; 4 - генераторный узел АХА

Рисунок 9 - Варианты выполнения бытового комбинированного прибора абсорбционного типа с произвольным расположением ТК: а) ТК находится на уровне или выше ХК; б) ТК находится ниже ХК.

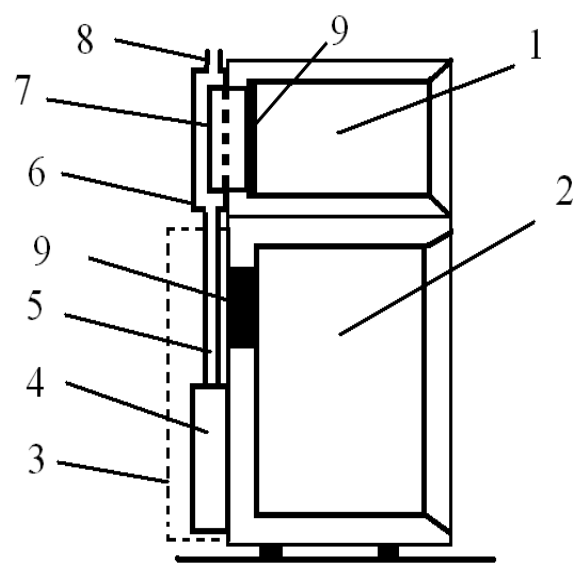

a)

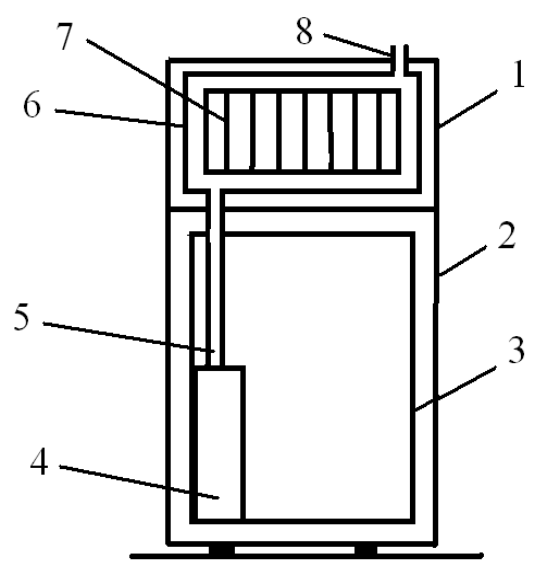

б)

1 - ТК; 2 - ХК; 3 - АХА на задней стенке холодильного шкафа; 4 - генераторный узел АХА; 5 - вытяжной канал отходящих газов; 6 - кожух ТК; 7 - оребрение; 8 - вентиляционная система; 9 - задняя стенка ТК.

Рисунок 10 - Конструкция бытового комбинированного прибора абсорбционного типа с горелочным устройством: а) вид сбоку; б) вид сзади.

Задняя стенка 9 внутреннего корпуса ТК 1 имеет наружное оребрение 7 в виде вертикальных ребер. Отходящие газы из генераторного узла 4 по теплоизолированному каналу 5 поступают в кожух 6 , установленный на задней стенке ТК 1, а затем выходят в вентиляционную систему по каналу 8.

Как показали оценочные расчеты, тепловой поток к ТК от отходящих газов может составить от 60 до 90 Вт, что превышает возможности способа использования бросового тепла цикла АХА.

Недостаток схемы с использованием тепла отходящих газов связан с необходимостью частой очистки тепловоспринимающих поверхностей ТК от образующейся в процессе эксплуатации сажи.

\section{Экспериментальные исследования бытовых комбинированных приборов абсорбционного типа}

Целью экспериментальных исследований являлось определение характеристик бытовых комбинированных приборов абсорбционного типа.

Объектами исследований являлись опытные конструкции бытовых комбинированных приборов абсорбционного типа, изготовленные на базе модели абсорбционного однокамерного холодильника с НТО типа «Кристалл-408» АШ-150 [4-6].

Изучались модели с ТК воздушного типа и в виде емкости для жидкости. Во всех случаях наружные гео- 
метрические параметры ТК составляли: высота 0,42 м; глубина - 0,54 м; ширина - 0,57 м; полезный

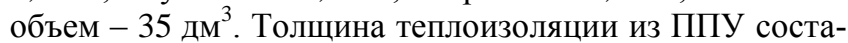
вила: боковых стенок - 80 мм; дна - 75 мм; крышки, задней и передней стенок - 10 мм. В ТК, выполненной в виде емкости для жидкости, внутренний корпус был изготовлен в виде целостного короба. Материал короба - нержавеющая сталь. Толщина стенки короба - 1 мм. Внутренний корпус ТК воздушного типа изготовлен из алюминия. Толщина стенки корпуса -3 мм. Для обеспечения тепловой связи подъемного участка дефлегматора АХА с ТК использовался ДФТС длиной 1,2 м и диаметром - 10×1 мм. Материал корпуса ДФТС - нержавеющая сталь. Теплоноситель - этиловый спирт.

Крепление ДФТС к дефлегматору диаметром $16 \times 1,4$ мм осуществлялось при помощи медной обжимающей пластины, причем для снижения термического сопротивления в зоне контакта находился сжатый ВПЯМ на основе меди, поры которого были заполнены теплопроводной пастой КТП-8.

Во всех случаях испарительный участок ДФТС крепился в нижней части подъемного участка дефлегматора и устанавливался параллельно ему. Длина участка испарения ДФТС в исследованиях варьировалась путем изменения зоны тепловой связи с дефлегматором. Транспортная зона ДФТС закрывалась теплоизоляционным кожухом. Длина конденсационного участка ДФТС не изменялась и составляла - 0,3 м.

Для сокращения времени выхода на стационарный режим в ТК был предусмотрен дополнительный электрический нагреватель с мощностью 190 Вт.

Исследование режимов работы бытовых комбинированных приборов абсорбционного типа осуществлялось в климатической камере лаборатории перспективного проектирования В3X как в стационарном (в «жестких» условиях работы холодильника $-t_{o . c}=32^{\circ} \mathrm{C}$, КРВ $=1)$, так и в переходных $\left(t_{o . c}<32{ }^{\circ} \mathrm{C}, \mathrm{KPB}<1\right)$ режимах работы AXА.

В процессе проведения испытаний фиксировались: температуры в характерных точках холодильного шкафа, ТК и AXA; тепловая нагрузка генератора AXA; температура окружающей среды; суточное энергопотребление.

Проведенные экспериментальные исследования показали, что при температуре окружающего воздуха $32{ }^{\circ} \mathrm{C}$ и 30 литрах воды в ТК нагрев воды от 21 до $50{ }^{\circ} \mathrm{C}$ осуществлялся за 5 часов. При этом АХА работал в постоянном режиме с тепловой мощностью на генераторе 110 Вт и был включен дополнительный нагреватель. Следует отметить, что в этом режиме АХА работал с запасом по холодильной мощности испарителя (средние температуры в ХК были ниже $0{ }^{\circ} \mathrm{C}$, а в НТО приближались к минус $\left.18^{\circ} \mathrm{C}\right)$. В дальнейшем тепловая нагрузка на генератор была снижена до 75 Вт, дополнительный нагреватель был отключен, температуры воздуха в климатической камере была снижена с $32{ }^{\circ} \mathrm{C}$ до $25^{\circ} \mathrm{C}$. После этого тепловой режим ТК стабилизировался и в течение 2,3 часа температура воды не изменялась.

С уровня тепловой нагрузки генератора 75 Вт был произведен переход на уровень 110 Вт и в течение 9,5 часов аппарат работал при температуре $25^{\circ} \mathrm{C}$. После этого был зафиксирован рост температуры воды в ТК с 53,5 до $56,5^{\circ} \mathrm{C}$.

Исследования показали, что ДФТС, передающий теплоту дефлегмации в ТК, заполненную жидкостью, позволяет поддерживать температуру в ней на уровне $50 . .60{ }^{\circ} \mathrm{C}$ путем компенсации потерь тепла в окружающую среду.

Изучался также режим работы при переходе с большей тепловой нагрузки генератора (110 ВТ) на меньшее значение (60 Вт). При температуре окружающего воздуха $25^{\circ} \mathrm{C}$ в течение 8,5 часов работы было зафиксировано снижение температуры в ТК с 56 до $53,5^{\circ} \mathrm{C}$, т.е. в режиме минимального энергопотребления не наблюдалось существенного снижения температуры в ТК, при этом температура в ХК не превышала плюс $4{ }^{\circ} \mathrm{C}$, а в НТО - минус $20^{\circ} \mathrm{C}$.

Проведено изучение пускового режима нагрева ТК без дополнительного нагревателя. Температура воды в начальный момент составляла $13,0^{\circ} \mathrm{C}$ при температуре окружающего воздуха $32{ }^{\circ} \mathrm{C}$. АХА работал при тепловой мощности генератора 110 Вт в течение 36 часов, после чего температура воды в ТК достигла $31{ }^{\circ} \mathrm{C}$. Температура в ХК в этих исследованиях не превышала $0{ }^{\circ} \mathrm{C}$, а в НТО составила около минус $16{ }^{\circ} \mathrm{C}$.

Таким образом, в период пуска в ТК, заполненной жидкостью, целесообразно использовать дополнительный источник тепла, который поможет произвести начальный нагрев за 4,5...5,5 часов.

Суточное энергопотребление при работе бытового комбинированного прибора в режиме компенсации тепловых потерь в ТК составило в среднем 1,50 кВт.час т.е. не превышало нормативный показатель (1,65 кВт.час [20]).

Результаты экспериментальных исследований бытовых комбинированных приборов абсорбционных приборов с ТК воздушного типа приведены на рис.11.

Выход на рабочий режим ТК при работе с номинальной тепловой нагрузкой генератора (110 ВТ) в них осуществляется за время около 13 часов, при этом температура в ТК достигала $70{ }^{\circ} \mathrm{C}$. При работе в энергосберегающих режимах (тепловая нагрузка генератора 70 ВТ) выход на уровень температур в ТК порядка $60{ }^{\circ} \mathrm{C}$ осуществляется за 45 часов.

Здесь можно сделать аналогичный вывод о целесообразности дополнительных затрат энергии в пусковой период. Эта задача может быть решена и при помощи аккумуляторов тепла, установленных в объеме теплоизоляции стенок ТК.

При выходе на стационарный режим происходит нагрев всех элементов конструкции ТК и они выполняют роль своеобразных аккумуляторов тепла. Пульсации температур в объеме ТК в этом случае минимальны и дополнительных затрат тепла не требуется.

В результате экспериментальных исследований была определена оптимальная длина испарительного участка ДФТС - для всех случаев она составила около 150 мм. Длина была определена из условия, чтобы на выходе зоны контакта дефлегматора и испарителя ДФТС температура стенки дефлегматора была не ниже $70{ }^{\circ} \mathrm{C}$. 


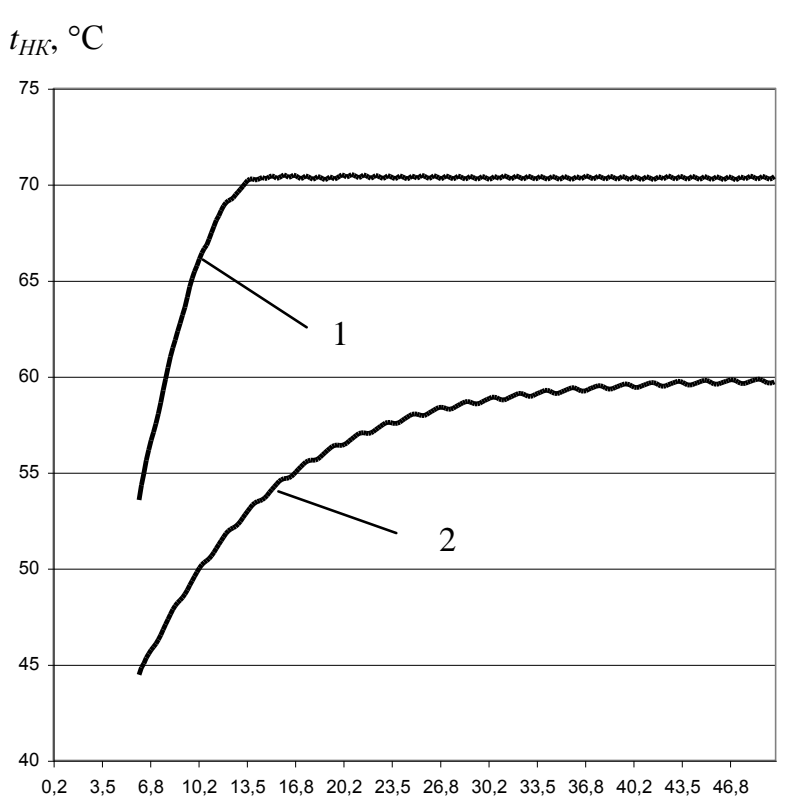

Рисунок 11 - Пусковые режимы ТК воздушного типа бытового комбинированного прибора абсорбционного типа при различных режимах работы АХА.

Тепловая нагрузка генератора: 1 - 110 Вт; 2 - 70 Вт).

Таким образом, проведенные экспериментальные исследования показали, что введение в состав абсорбционного холодильника дополнительной ТК, связанной в тепловом отношении с подъемным участком дефлегматора AXA, не приводит к росту энергопотребления (по результатам испытаний ниже, чем в серийном исполнении, на $5 \%$ ) и не ухудшает эксплуатационных характеристик камер охлаждения.

\section{Выводы}

1. Перспективным направлением энергосбережения в бытовой технике может стать разработка приборов, совмещающих функции холодильного хранения и тепловой обработки пищевых продуктов, полуфабрикатов и сельскохозяйственного сырья. В таких бытовых комбинированных приборах теплота, выделяющаяся при реализации холодильного цикла, не отводится сразу в окружающую среду, а передается в специальную ТК, при этом в объеме ТК поддерживается температура выше, чем температура воздуха в помещении. Эффект энергосбережения достигается за счет расширения функциональных возможностей бытовых приборов без привлечения дополнительных энергозатрат.

2. Для реализации в быту подавляющего числа пищевых технологий достаточным является диапазон температур $50 \ldots 70{ }^{\circ} \mathrm{C}$. В современной бытовой холодильной технике такой диапазон температур могут обеспечить только АХА, при этом в качестве источника тепловой нагрузки дополнительной ТК следует использовать подъемный участки дефлегматора.

3. Проведена классификация бытовых комбинированных приборов абсорбционного типа по функциональному назначению ТК, способу передачи тепла от элементов АХА к ТК, расположению ТК относительно холодильного шкафа, конструктивному исполнению ТК и источникам тепловой энергии ТК.
4. Предложены оригинальные конструкции комбинированных бытовых аппаратов абсорбционного типа, приведено описание их работы, преимущества и недостатки, области применения. Показаны перспективы применения моделей с горелочными источниками тепловой нагрузки АХА и конструкций с гибкими теплопередающими устройствами.

5. Результаты экспериментальных исследований бытовых комбинированных приборов абсорбционного типа на базе серийной модели ВЗХ "Кристалл - 408" АШ-150 показали:

а) для снижения энергопотребления в пусковой период целесообразно использовать дополнительные источники тепловой нагрузки для обеспечения приемлемых тепловых режимов ТК, причем эту задачу можно решить и при использовании теплоаккумулирующих материалов;

б) введение в состав бытовых абсорбционных холодильников дополнительной ТК, связанной в тепловом отношении с подъемным участком дефлегматором AXА, не приводит к росту энергопотребления (по результатам испытаний ниже, чем в серийном исполнении, на 5 \%) и не ухудшает эксплуатационных характеристик камер охлаждения.

\section{Литература}

1. Титлов А. С. Альтернативная бытовая и торговая холодильная техника на базе водоаммиачных абсорбционно-диффузионных холодильных машин / А. С. Титлов // Холодильная техника. - 2003. - № 4. С. 9-12.

2. Титлов А. С. Соврем6енный уровень разработок и производства бытовых абсорбционных холодильных приборов и их экономическая эффективность / А. С. Титлов // Энергосбережение. Энергетика. Энергоаудит. - 2007. - № 9. - С. 9-17.

3. Титлов А.С. Современный уровень разработок и производства бытовых абсорбционных холодильных приборов / А.С. Титлов // Холодильный бизнес. - 2007. - № 8. - С. 12-17; № 9. - С. 28-30; № 10. - С. 47-49 ; № 11. - C. 46-47.

4. Титлов А.С. Новое направление развития бытовой холодильной техники / А. С. Титлов // Тепловые режимы и охлаждение радиоэлектронной аппаратуры -1993. - № 2 - С. 61-63.

5. Тележенко Л.М. Розробка нового типу побутових комбінованих приладів / Л.М. Тележенко, О.С. Тітлов, С.В. Вольневич, Ю.О. Козонова // Наукові праці Одеської національної академії харчових технологій. - 2009. - № 35. - T.1. - С. 22-25.

6. Титлов А.С. Разработка и экспериментальные исследования бытовых комбинированных приборов абсорбционного типа, совмещающих функции холодильного хранения и тепловой обработки / А.С. Титлов, С.В. Вольневич, Ю.А. Козонова // Збірник наукових праць НУК. - 2013. - № 5-6. - С.47-50.

7. Титлов, А.С. Анализ технологических возможностей дополнительной тепловой камеры в составе бытового абсорбционного холодильного прибор / А.С. Титлов, Ю.А. Козонова, В.Г. Приймак // Казахстан-Холод 2017: Сб. докл. межд.науч.-техн. конф. (15-16 марта 2017 г.) - Алматы: АТУ, 2017. - С. 225-228. 
8. Тележенко Л.М. Розробка нового типу побутових приладів / Л.М. Тележенко, О.С. Тітлов, С.В. Вольневич, Ю.О. Козонова // Збірник наукових праць Вінницького національного аграрного університету. Серія: Технічні науки. - Вип. 7. - 2011. - С.36-40.

9. Пат. 1814006 Российская Федерация, МПК F 25 D 11/02. Комбинированный абсорбционный холодильник / В. Ф. Чернышов, В. В. Двирный, Г. И. Овечкин (РФ), А. С. Титлов (Украина), К. Г. Смирнов-Васильев (РФ), Н. Ф. Хоменко (Украина), В. Х. Демтиров (РФ), Г. И. Григоров (РФ), Г. М. Олифер (Украина) - № 4890425/06 ; заявл. 13.12.90 ; опубл. 07.05.93, Бюл. № 17.

10. Пат. 1814007 Российская Федерация, МПК F 25 D 11/02. Комбинированный абсорбционный холодильник / А. С. Титлов (Украина), В. Ф. Чернышов, В. В. Двирный, Г. И. Овечкин, К. Г. Смирнов-Васильев (РФ), Н. Ф. Хоменко, Г. М. Олифер (Украина), В. Х. Демтиров, Г. И. Григоров (РФ). - № 4890427/06 ; заявл. 13.12.90 ; опубл. 07.05.93, Бюл. № 17.

11. Пат. 1814008 Российская Федерация, МПК F 25 D 11/02. Комбинированный абсорбционный холодильник / В. Ф. Чернышов, В. В. Двирный (РФ), А. С. Титлов (Украина), Г. И. Овечкин, К. Г. Смирнов-Васильев (РФ), Н. Ф. Хоменко (Украина), В. Х. Демтиров, Г. И. Григоров (РФ), Г. М. Олифер. (Украина). - № $4890428 / 06$; заявл. 13.12.90 ; опубл. 07.05.93, Бюл. № 17.

12. Деклараційний патент № 47866А Україна, МПК $^{7} \mathrm{~F}$ 25 D 11/02. Комбінований абсорбційний холодильник / О. С. Тітлов, М. Д. Захаров, О. Б. Василів, С. В. Вольневич (Україна). - № 2001106933 ; заявл. 11.10.01 ; опубл. 15.07.02, Бюл. № 7.

13. Деклараційний патент № 47751А Україна, МПК $^{7} \mathrm{~F}$ 25 В 15/10. Комбінований абсорбційний холодильник / О. С. Тітлов, М. Д. Захаров, О. Б. Василів, С. В. Воль- невіч (Україна). - № 2001096073 ; заявл. 04.09.2001 ; опубл. 15.07.02, Бюл. № 7 .

14. Титлов А. С. Экспериментальные исследования температурно-энергетических характеристик низкотемпературных камер на основе АДХМ / А. С. Титлов, В. В. Завертаный, О. Б. Васылив, Л. Р. Ленский // Тепловые режимы и охлаждение радиоэлектронной аппаратуры. - 1998. - № 1. - С. 60-67.

15. Титлов А. С. Поиск и изучение перспективных теплоизоляционных материалов генераторных узлов АДХМ / А. С. Титлов, Н. В. Рева, Д. С. Тюхай // Холодильная техника и технология. - 2001. - № 3. C. $12-18$.

16. Титлова О.А., Хобин В.А. Энергоэффективное управление абсорбционными холодильниками. Херсон: Гринь Д.С., 2014. - 216 с.

17. Титлов А. С. Перспективы использования эффекта осмоса в холодильной технике / А. С. Титлов, С. В. Вольневич, О. Б. Васылив, В. Н. Халайджи // Холодильная техника и технология. - 2000. - № 69. - С. 24 32.

18. Дытнерский Ю. И. Баромембранные процессы. Теория и расчет / Ю. И. Дытнерский. - М. : Химия, 1986.$272 \mathrm{c}$.

19. Титлов А. С. Разработка транспортных холодильников для фермерских и крестьянских хозяйств на основе абсорбционно-диффузионных холодильных машин / А. С. Титлов, А. Ю. Кагальский // Наукові праці Одес. нац. акад. харч. технологій. - 2006. - № 28. - Т. 1. - С. 179186.

20. Прилади холодильні електричні побутові. Загальні технічні умови : ДСТУ 2295-93 (ГОСТ 16317-95 ISO 5155-83, ISO 7371-85, IEC 335-2-24-84).- [Чинний від 1995-7-20] - К. : Держстандарт України, 1996. - 35 с. (Національний стандарт України)

Отримана в редакції 04.02.2018, прийнята до друку 06.03.2018

\title{
Development of domestic combined instrument absorption type
}

\author{
A. S. Titlov, Yu. A. Kozonova, V. G. Priymak \\ Odessa national academy of food technologies, Kanatnay str., 112, Odessa, Ukraine, 65039
}

The current transition of refrigeration technology to natural working substances forces developers to reconsider the attitude towards absorption refrigeration devices (AHP) that are equipped with absorption cooling units (AXA) and can be considered as one of the alternative options for switching to natural refrigerants. The working substance of AXA consists of an aqueous ammonia solution (VAP) with the addition of an inert gas (hydrogen, helium or a mixture thereof) and is absolutely environmentally safe - it has zero ozone-depleting potential and potential of the "greenhouse" effect. At the same time, AHP have an increased energy consumption compared to similar compression models. In our opinion, this situation is due not only to the imperfection of their refrigerating cycle, but also to the lack of appropriate scientific and engineering developments. Analysis of thermal regimes of AXA showed that a promising direction in energy saving could be the development of household appliances that combine the functions of cold storage and heat treatment of food, semi-finished products and agricultural raw materials. In such combined household appliances, the heat released during the implementation of the refrigeration cycle is not diverted to the environment, but is sent to a special thermal chamber (TK). In the volume of the TK, the temperature is maintained higher than the air temperature in the room. The energy saving effect is achieved due to the fact that the temperature conditions in the TK are maintained without additional energy consumption. At the preliminary stage of development of household combined devices, the analysis of technologies using heat treatment of products, semi-finished products and raw materials was given. It is shown that for realizing in the everyday life of the overwhelming number of food technologies, the temperature range $50 \ldots 70^{\circ} \mathrm{C}$ is sufficient. In modern domestic refrigeration such a temperature range can only be provided by the AXA, while using the elevating parts of the reflux as the source of the heat load of the additional TK. Classification of household combined devices of absorption type according to the functional purpose of the TK, the method of heat transfer from AXA to TK elements, the location of the TK relative to the refrigerating cabinet, the design of the TK and the thermal energy sources of the TK are carried out. Original designs of combined household devices of absorption type are offered, the description of their work, advantages and disadvantages, fields of application is given. The prospects of application of models with burners of AXA heat load and designs with flexi- 
ble heat transfer devices are shown. The results of experimental studies of household combined absorption devices on the basis of the serial model VZH "Crystal-408" AW-150 showed: a) to reduce energy consumption during the start-up period, it is advisable to use additional sources of heat load to ensure acceptable thermal conditions of the TK, and this task can be solved with the use of heat-storage materials; $b$ ) the introduction of additional TK into the composition of household absorption refrigerators, which is related in thermal relation with the elevating section by the AHA reflux condenser, does not lead to an increase in energy consumption (according to the results of tests lower than in the standard version, by 5\%) and does not impair the performance chambers of cooling.

Keywords: household appliances, energy saving, combined absorption refrigeration device, additional thermal chamber

\section{References}

1. Titlov A. S. Al'ternativnaya bytovaya i torgovaya kholodil'naya tekhnika na baze vodoammiachnykh absorbtsionno-diffuzionnykh kholodil'nykh mashin / A. S. Titlov // Kholodil'naya tekhnika. - 2003. - № 4. - S. 9-12.

2. Titlov A. S. Sovrem6ennyy uroven' razrabotok i proizvodstva bytovykh absorbtsionnykh kholodil'nykh priborov i ikh ekonomicheskaya effektivnost' / A. S. Titlov // Energosberezheniye. Energetika. Energoaudit. - 2007. - № 9. - S. 9-17.

3. Titlov A.S. Sovremennyy uroven' razrabotok i proizvodstva bytovykh absorbtsionnykh kholodil'nykh priborov / A.S. Titlov // Kholodil'nyy biznes. - 2007. - № 8. - S. 1217; № 9. - S. 28-30; № 10. - S. 47-49 ; № 11. - S. 46-47.

4. Titlov A.S. Novoye napravleniye razvitiya bytovoy kholodil'noy tekhniki / A. S. Titlov // Teplovyye rezhimy i okhlazhdeniye radioelektronnoy apparatury -1993 . - № $2-$ S. 61-63.

5. Telezhenko L.M. Rozrobka novogo tipu pobutovikh kombínovanikh priladív / L.M. Telezhenko, O.S. Títlov, S.V. Vol'nevich, YU.O. Kozonova // Naukovi pratsi Odes'koï natsíonal'noî akademîi kharchovikh tekhnologíy. 2009. - № 35. - T.1. - S. 22-25.

6. Titlov A.S. Razrabotka i eksperimental'nyye issledovaniya bytovykh kombinirovannykh priborov absorbtsionnogo tipa, sovmeshchayushchikh funktsii kholodil'nogo khraneniya i teplovoy obrabotki / A.S. Titlov, S.V. Vol'nevich, YU.A. Kozonova // Zbírnik naukovikh prats' NUK. - 2013. - № 5-6. - S.47-50.

7. Titlov, A.S. Analiz tekhnologicheskikh vozmozhnostey dopolnitel'noy teplovoy kamery $\mathrm{v}$ sostave bytovogo absorbtsionnogo kholodil'nogo pribor / A.S. Titlov, YU.A. Kozonova, V.G. Priymak // Kazakhstan-Kholod 2017: Sb. dokl. mezhd.nauch.-tekhn. konf. (15-16 marta 2017 g.) Almaty: ATU, 2017. - S. 225-228.

8. Telezhenko L.M. Rozrobka novogo tipu pobutovikh priladív / L.M. Telezhenko, O.S. Títlov, S.V. Vol'nevich, YU.O. Kozonova // Zbírnik naukovikh prats' Vínnits'kogo natsíonal'nogo agrarnogo uníversitetu. Seríya: Tekhníchní nauki. - Vip. 7. - 2011. - S.36-40.

9. Pat. 1814006 Rossiyskaya Federatsiya, MPK5 F 25 D $11 / 02$. Kombinirovannyy absorbtsionnyy kholodil'nik / V. F. Chernyshov, V. V. Dvirnyy, G. I. Ovechkin (RF), A. S. Titlov (Ukraina), K. G. Smirnov-Vasil'yev (RF), N. F. Khomenko (Ukraina), V. KH. Demtirov (RF), G. I. Grigorov (RF), G. M. Olifer (Ukraina) - № 4890425/06 ; zayavl. 13.12.90; opubl. 07.05.93, Byul. № 17.

10. Pat. 1814007 Rossiyskaya Federatsiya, MPK5 F 25 D 11/02. Kombinirovannyy absorbtsionnyy kholodil'nik / A. S. Titlov (Ukraina), V. F. Chernyshov, V. V. Dvirnyy, G. I. Ovechkin, K. G. Smirnov-Vasil'yev (RF), N. F. Khomenko, G. M. Olifer (Ukraina), V. KH. Demtirov, G. I. Grigorov (RF). - № 4890427/06 ; zayavl. 13.12.90 ; opubl. 07.05.93, Byul. № 17 .
11. Pat. 1814008 Rossiyskaya Federatsiya, MPK5 F 25 D $11 / 02$. Kombinirovannyy absorbtsionnyy kholodil'nik / V. F. Chernyshov, V. V. Dvirnyy (RF), A. S. Titlov (Ukraina), G. I. Ovechkin, K. G. Smirnov-Vasil'yev (RF), N. F. Khomenko (Ukraina), V. KH. Demtirov, G. I. Grigorov (RF), G. M. Olifer. (Ukraina). - № 4890428/06 ; zayavl. 13.12.90 ; opubl. 07.05.93, Byul. № 17.

12. Deklaratsíyniy patent № 47866A Ukraïna, MPK7 F 25 D 11/02. Kombínovaniy absorbtsíyniy kholodil'nik / O. S. Títlov, M. D. Zakharov, O. B. Vasilív, S. V. Vol'nevich (Ukraïna). - № 2001106933 ; zayavl. 11.10.01 ; opubl. 15.07.02, Byul. № 7 .

13. Deklaratsíyniy patent № 47751A Ukraïna, MPK7 F 25 B 15/10. Kombínovaniy absorbtsíyniy kholodil'nik / O. S. Títlov, M. D. Zakharov, O. B. Vasilív, S. V. Vol'nevích (Ukraïna). - № 2001096073 ; zayavl. 04.09.2001 ; opubl. 15.07.02, Byul. № 7 .

14. Titlov A. S. Eksperimental'nyye issledovaniya temperaturno-energeticheskikh kharakteristik nizkotemperaturnykh kamer na osnove ADKHM / A. S. Titlov, V. V. Zavertanyy, O. B. Vasyliv, L. R. Lenskiy // Teplovyye rezhimy i okhlazhdeniye radioelektronnoy apparatury. - 1998. - № 1. - S. 60-67.

15. Titlov A. S. Poisk i izucheniye perspektivnykh teploizolyatsionnykh materialov generatornykh uzlov ADKHM / A. S. Titlov, N. V. Reva, D. S. Tyukhay // Kholodil'naya tekhnika i tekhnologiya. - 2001. - № 3. - S. 1218.

16. Titlova O.A., Khobin V.A. Energoeffektivnoye upravleniye absorbtsionnymi kholodil'nikami. Kherson: Grin' D.S., 2014. - $216 \mathrm{~s}$.

17. Titlov A. C. Perspektivy ispol'zovaniya effekta osmosa v kholodil'noy tekhnike / A. S. Titlov, S. V. Vol'nevich, O. B. Vasyliv, V. N. Khalaydzhi // Kholodil'naya tekhnika i tekhnologiya. - 2000. - № 69. - S. 24-32.

18. Dytnerskiy YU. I. Baromembrannyye protsessy. Teoriya i raschet / YU. I. Dytnerskiy. - M. : Khimiya, 1986.$272 \mathrm{~s}$.

19. Titlov A. S. Razrabotka transportnykh kholodil'nikov dlya fermerskikh i krest'yanskikh khozyaystv na osnove absorbtsionno-diffuzionnykh kholodil'nykh mashin / A. S. Titlov, A. YU. Kagal'skiy // Naukoví pratsí Odes. nats. akad. kharch. tekhnologíy. - 2006. - № 28. - T. 1. - S. 179-186.

20. Priladi kholodil'ní yelektrichní pobutoví. Zagal'ní tekhníchní umovi : DSTU 2295-93 (GOST 16317-95 ISO 5155-83, ISO 7371-85, IEC 335-2-24-84).- [Chinniy víd 1995-7-20] - K. : Derzhstandart Ukraïni, 1996. - 35 s. (Natsíonal'niy standart Ukraïni).

Received 04 February 2018 Approved 06 March 2018 Available in Internet 30 April 2018 